\title{
Heat recovery of dedusting systems in electric arc furnaces: concept of a bottoming cogeneration plant and techno-economic analysis
}

\author{
Cesar Augusto Arezo e Silva Jr. ${ }^{1} \cdot$ José Alexandre Matelli ${ }^{1}$ if
}

Received: 8 September 2017 / Accepted: 6 November 2017 / Published online: 30 December 2017

(C) The Brazilian Society of Mechanical Sciences and Engineering 2017

\begin{abstract}
Steelworks require large amount of energy in reduction, fusion and refining processes. A mini-mill is a steelwork that produces steel by melting scrap metal, pig iron and metallic elements in electric arc furnaces. Depending on the desired product, the refining process requires vacuum degassing to remove contaminant gases from the liquid steel. The vacuum in the degassing process can be obtained through steam ejectors, which use superheated steam. Furthermore, environmental legislation requires mini-mills to have dedusting systems over the electric furnaces. In general, a dedusting system generates high flow rates of hot off-gases, which indicates an interesting potential for heat recovering. In this paper, a cogeneration plant to recover heat from the dedusting system of a Brazilian mini-mill is proposed. The actual operation data are considered to calculate the heat available and to conceptualize a bottoming cogeneration plant that generates electric power and superheated steam for the ejectors of the degassing process. Results show that the proposed plant can generate $45.4 \%$ of the steam required by the ejectors and up to $2.4 \%$ of the power required by the electric arc furnace. Also, the heat recovering from the dedusting system reduces the use of cooling water by $29.3 \%$. From an economic viewpoint, the cogeneration plant decreased the expenses for power, steam and cooling water by $1.5,32$ and $29 \%$, respectively. Overall, there was an expense reduction of $4.8 \%$, resulting in a payback period of 4.1 years in the case base. For a projected best case scenario, the payback period is about 2.3 years.
\end{abstract}

Keywords Mini-mill $\cdot$ Electric arc furnace $\cdot$ Heat recovery $\cdot$ Cogeneration

\section{Nomenclature}

\section{List of symbols}

$b_{\mathrm{p}} \quad$ Bypass ratio [-]

C Specific cost [USD/MWh]

$c_{\mathrm{p}} \quad$ Specific heat $[\mathrm{kJ} / \mathrm{kgK}]$

$D_{\mathrm{t}} \quad$ Tube diameter $[\mathrm{m}]$

$E \quad$ Expense [USD/year]

$f \quad$ Annuity factor [-]

$H \quad$ Annual operating time [h]

$h \quad$ Specific enthalpy $[\mathrm{kJ} / \mathrm{kg}]$

Technical Editor: Jose A. dos Reis Parise.

José Alexandre Matelli

matelli@feg.unesp.br

Cesar Augusto Arezo e Silva Jr. cesar.arezo@hotmail.com

1 School of Engineering, Department of Energy, São Paulo State University (UNESP), Guaratinguetá, SP, Brazil
I Investment cost [USD]

$j \quad$ Annual interest rate [-]

$k \quad$ Plant useful life [years]

$L \quad$ Length [m]

$m$ Mass [kg]

$\dot{m} \quad$ Mass flow $[\mathrm{kg} / \mathrm{s}]$

$N_{\mathrm{t}} \quad$ Number of tubes [-]

$P \quad$ Pressure [kPa]

pb Payback [year]

$q \quad$ Heat transfer rate $[\mathrm{kW}]$

$R$ Revenue [USD/year]

$r_{\mathrm{ev}}$ Evaporation rate [-]

$s \quad$ Specific entropy $[\mathrm{kJ} / \mathrm{kgK}]$

$T$ Temperature $\left[{ }^{\circ} \mathrm{C}\right]$

$t \quad$ Time [s]

$\dot{W} \quad$ Work transfer rate, power [kW]

\section{Greek letters}

$\Delta$ Difference

$\eta \quad$ Efficiency [-]

$\rho \quad$ Specific mass $[\mathrm{kg} / \mathrm{m}]$ 


\section{Subscripts}

ap Approach point

b Gas-fired boiler

c Colder than average condenser

cl Cycle

cur Current situation

cw Cooling water

d Degassing process

e Electric energy

ec Economizer section

ev Evaporator section

g Off-gas power generator

$\mathrm{h}$ Hotter than average

he Heat exchanger

i Inlet

$i, j, k \quad$ Indexes, counting variables

1 Loss

ng Natural gas

o Outlet

om Operation and maintenance

$\mathrm{p} \quad$ Pump

pp Pinch point

sat Saturation

sg (heat recovery) Steam generator

sh Superheater section

sl Salt

st Steam

t Turbine

tr Thermal reservoir

\section{Superscripts}

cg Cogeneration

off Ejector off

on Ejector on $[-]$

$\begin{array}{ll}\text { Abbreviations } \\ \text { ABNT } & \text { Brazilian Association of Tech. Standards } \\ \text { EAF } & \text { Electric arc furnace } \\ \text { HRSG } & \text { Heat recovering steam generator } \\ \text { LHV } & \text { Lower heating value } \\ \text { NBR } & \text { Brazilian standard } \\ \text { O\&M } & \text { Operation and maintenance } \\ \text { TR } & \text { Thermal reservoir }\end{array}$

\section{Introduction}

Rational use of energy is a major priority in Brazilian industry since the energy rationing in 2001. Just recently, hydro power plants' reservoirs were nearly empty, demanding the use of pollutant and expensive thermal power plants for long periods of time. Furthermore, global competition keeps demanding the reduction of production cost. Depending on the industrial sector, energy cost is a significant share of total production costs. In steelworks, this share is about $20 \%$. In integrated steel mills, up to $75 \%$ of energy demand comes from fossil fuels and $64 \%$ of the total energy demand of a mini-mill is electric energy [1].

The main characteristics of a mini-mill are the use of metal scrap and pig iron as raw materials and the highly intensive use of electric power in melting and refining processes. Liquid steel is obtained in electric arc furnaces (EAF), where electric energy is converted to heat. The heat is then transferred to the metal load inside the furnace, where a temperature as high as $1600^{\circ} \mathrm{C}$ is reached for load melting. Electric energy to melt the metallic load in is about $50 \%$ of the total energy required in the EAF; $40 \%$ is provided by exothermic reactions within the furnace; and $10 \%$ is due to natural gas combustion and coal addition to the metallic bath [2]. The amount of energy that effectively melts the load is about $1314 \mathrm{~kJ} / \mathrm{kg}(365 \mathrm{kWh} / \mathrm{t})$ and the heat loss with the off-gases is about $813.6 \mathrm{~kJ} / \mathrm{kg}(226 \mathrm{kWh} /$ t), which is close to $30 \%$ of the total furnace energy input [2]. A typical energy balance of an EAF is shown in Fig. 1.

Large amounts of particulate matter are generated during the steel melting. To avoid releasing these pollutants into the atmosphere, a dedusting system is required. This system presents high flow rate of hot gases with high concentration of particulate matter and carbon monoxide from the furnace. The carbon monoxide is burned in a combustion chamber and the particulate matter is filtered in a baghouse. To prevent fire, the gas stream must be cooled down upstream the baghouse. Thus, the heat contained in this stream is lost. Contaminant gases are also present in the liquid metal and, depending on the desired product, a degassing process may be required to remove these gases through vacuum generated by steam ejectors.

Most of the Brazilian mini-mills do not recover heat from dedusting systems, so that there is significant potential to increase the energy efficiency of the overall minimill process. Recent publications present studies of heat recovery opportunities in steel mills, most of them referring to integrated steel mills [3-7]. Heat recovery for power generation in mini-mills is found in the works of Pili et al. [8], Ramirez et al. [9] and Nardin et al [10]. None of these studies on heat recovery in steel mills (either integrated or mini) proposes the cogeneration of power and steam for industrial process, so that there is opportunity for an original contribution. The objective of this paper is to propose a bottoming cogeneration plant to recover heat from the dedusting system of a Brazilian mini-mill. Although it may be argued that the primary energy source is electric energy instead of heat from a burning fuel, in this work the term cogeneration is preferred in the sense that two utilities are simultaneously generated from heat recovery. The actual operation data are considered to calculate the heat available and to conceptualize a cogeneration plant that generates 
Fig. 1 Sankey diagram for a typical EAF (adapted from [2])
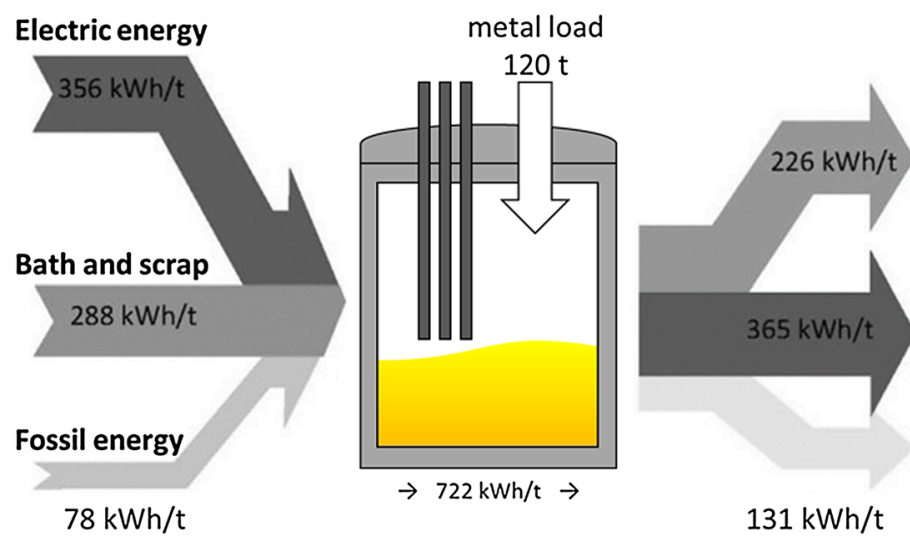

Exahust gases

Liquid

steel

Losses slag cooling radiation power and superheated steam for the ejectors of the degassing process. The use of a thermal reservoir to damp the influence of furnace transient operation (batch operation) on the cogeneration plant is also evaluated.

\section{Mini-mill description}

The mini-mill considered in this work is located in São Paulo State, Brazil. The nominal capacity of EAF is 90 tons of steel per batch, with 45 MVA of electric power. The EAF is able to process a whole batch in about 100 min. Normally, the EAF is not loaded at once, but rather divided into intermediate loads. In the first loading, the metal scrap fills the entire furnace volume. When melted, however, the liquid metallic mass occupies a much smaller volume, resulting in more room in the furnace for subsequent loadings. The EAF considered in this work can operate with three intermediate loads to complete its total capacity. After the whole batch is melted, the liquid steel is transferred to a ladle furnace for subsequent refining.

During the EAF operation, it remains closed to avoid the release of heat and potentially hazardous off-gases with significant amounts of carbon monoxide and particulate matter. Because of that, the resulting off-gases are sent to a combustion chamber for burning. Then, the resulting gases are cooled down to be safely filtered in the baghouse. This path is called primary line (Fig. 2). When the melting is done, the EAF is opened. That opening releases gases in the industrial shed where the furnace is installed. The shed has a canopy in the ceiling to aspire the gases through the secondary line. In both lines, the gases are driven by fans. Since a large amount of ambient air is aspired along with the gases in the canopy, the gases in the secondary line are much cooler, so that no further cooling is required upstream the baghouse. Primary and secondary lines and respective hardware are called dedusting system and is quite similar to that presented by Nardin et al. [10]. The mini-mill dedusting system is depicted in Fig. 2.
After slag removal, the liquid steel is transferred to a ladle for addition of chemicals to adjust the properties and equalization of steel temperature for subsequent conformation. Depending on the obtained steel, the vacuum degassing process is necessary before temperature equalization [11]. In this case, the ladle is put into a hermetically sealed vacuum furnace. The vacuum is obtained through steam ejectors that require up to $5.56 \mathrm{~kg} / \mathrm{s}(20 \mathrm{t} / \mathrm{h})$ of superheated steam at $1.50 \mathrm{MPa}$ and temperature no less than $200{ }^{\circ} \mathrm{C}$. Degassing is also a batch process; each batch lasts about $60 \mathrm{~min}$, during which the steam demand is equal to $20 \mathrm{t} / \mathrm{h}$ for $30 \mathrm{~min}$. For another $30 \mathrm{~min}$, there is no demand. Currently, the superheated steam is provided by two natural gas-fired, water-tube steam generators, each with a rated capacity of $5.56 \mathrm{~kg} / \mathrm{s}(20 \mathrm{t} / \mathrm{h})$ at $2.2 \mathrm{MPa}$. The boilers also provide $1.67 \mathrm{~kg} / \mathrm{s}(6 \mathrm{t} / \mathrm{h})$ of steam at $1.2 \mathrm{MPa}$ to another industrial process (Fig. 3).

The actual data from the data acquisition and controlling system of the mini-mill are considered in this work. Flow and temperature measures are taken in the primary line (Fig. 2) downstream the combustion chamber. Around 500,000 samples were collected during 40 days, which allowed to capture several different operational conditions for different steels produced in the EAF. Since off-gas flow is induced by the fan, the flow rate is equal to $253,500 \mathrm{Nm}^{3} / \mathrm{h}$, which is the nominal flow of the fan. Also, the flow rate is observed to be independent of the batch. Off-gas specific heat and specific mass are equal to $1.33 \mathrm{~kJ} /$ $\mathrm{Nm}^{3} \mathrm{~K}$ and $1.3 \mathrm{~kg} / \mathrm{Nm}^{3}$, respectively [10]. Off-gas temperature, on the other hand, presents significant variation. Table 1 presents consolidated data from 13 batches and 10 different products.

The instruments used to collect temperature data present errors of $\pm 1.5^{\circ} \mathrm{C}$. They are calibrated according to technical procedures specified in Brazilian standards issued by ABNT, such as NBR 13,863 and NBR 14,670. There is an instrumentation and control department responsible for the maintenance and calibration of all the measuring instruments and transducers used in the steelworks. The 


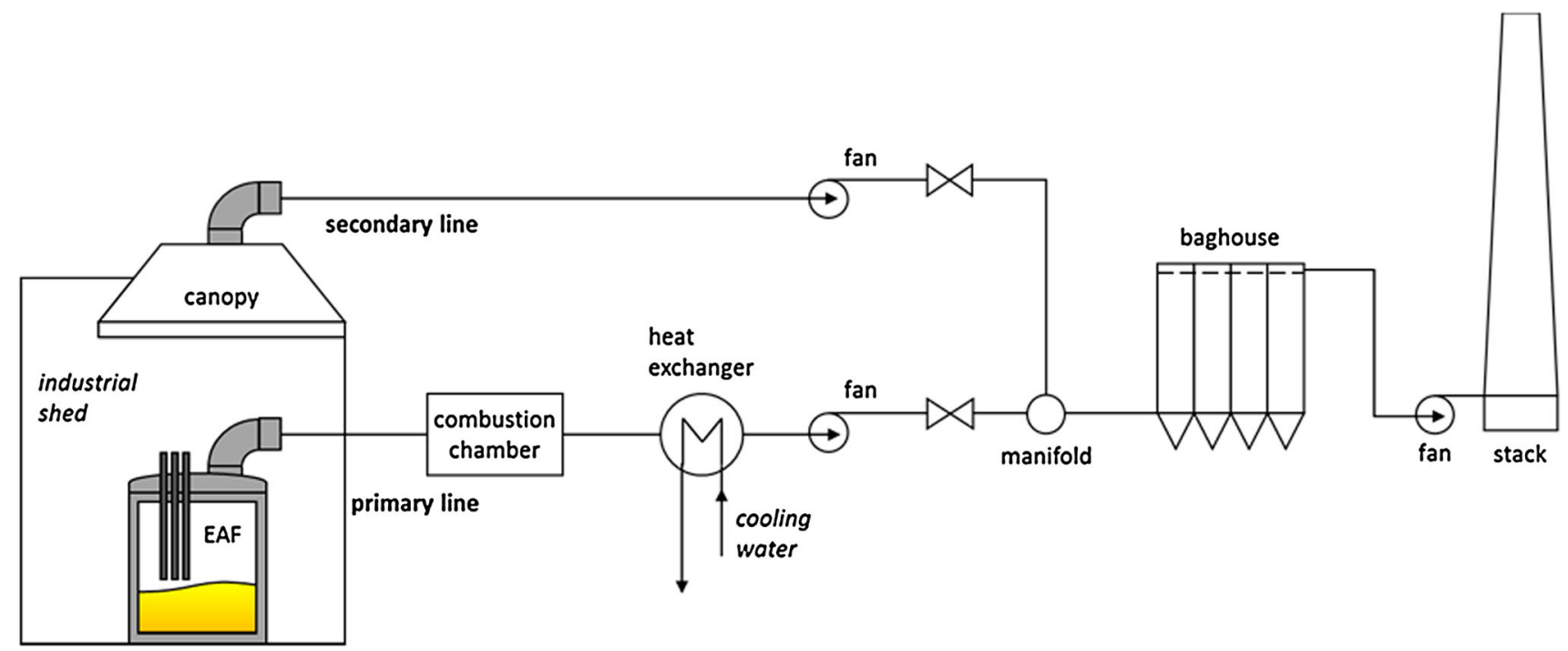

Fig. 2 Mini-mill dedusting system (adapted from [10])

Fig. 3 Steam generation for degassing and other industrial processes

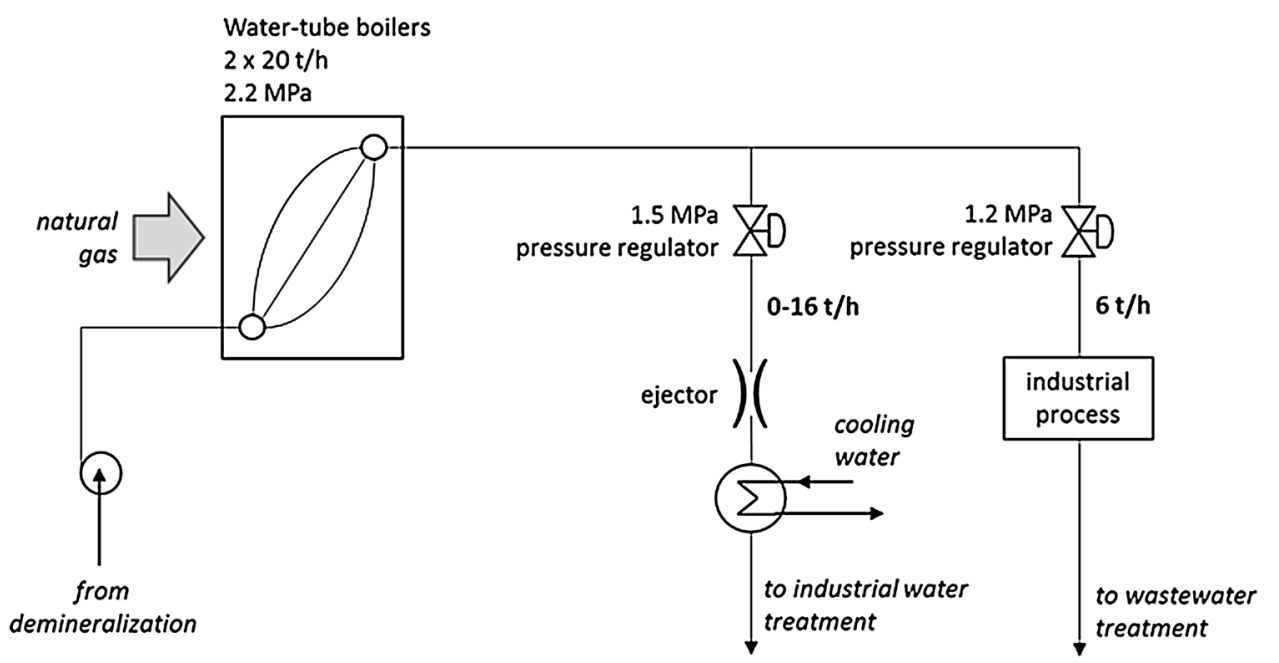

department has an accredited laboratory where calibrations are performed according a pre-defined schedule to assure a calibration confidence interval greater than $95 \%$.

Figure 4 shows the off-gas temperature profile for each batch and the resulting off-gas average temperature profile. It is interesting to note that the average profile allows to identify when the intermediate loadings and respective melting occur. It also should be emphasized that the actual operational performance of the plant would depend on the batch being processed, so that the average profile is a parameter to make design decisions and not a way to predict the plant performance. From data analysis of Fig. $4 \mathrm{~b}$, the overall average temperature is equal to $311.8^{\circ} \mathrm{C}$ and the off-gas presents temperature below the

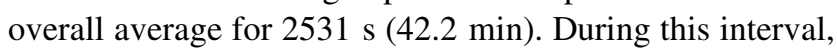
the off-gas average temperature is about $273.8^{\circ} \mathrm{C}$. Not surprisingly, the first load contributes the most to the interval on which off-gas temperature is lower than the average. This is an important design parameter for the cogeneration plant, since the plant is sized considering a heat source at the overall average temperature of $311.8^{\circ} \mathrm{C}$. During $42.2 \mathrm{~min}$, the gases would not have enough energy to drive the plant. On the other hand, when the gases have temperature above the average, there would be more energy than the plant needs. Off-gas temperature exceeds the overall average during $3979 \mathrm{~s}(66.3 \mathrm{~min})$ and, in this interval, the average off-gas temperature is about $336.1{ }^{\circ} \mathrm{C}$. Thus, a thermal reservoir should be considered: (i) to store heat from the gases when exceeding heat is available during $66.3 \mathrm{~min}$ and (ii) to provide heat to the plant during 42.2 min when the gases have less energy than required. The detailed conception and modeling of the cogeneration plant and the heat reservoir are presented next in Sect. 3. 
Table 1 Consolidated data from 13 batches in the EAF

\begin{tabular}{|c|c|c|c|c|c|c|c|c|}
\hline \multirow[t]{2}{*}{ Batch\# } & \multicolumn{3}{|c|}{ EAF operation time (min) } & \multirow{2}{*}{$\begin{array}{l}\text { Off-gas av. } \\
\text { temperature } \\
\left({ }^{\circ} \mathrm{C}\right)\end{array}$} & \multirow{2}{*}{$\begin{array}{l}\text { Energy } \\
\text { consumed } \\
\text { (GJ) }\end{array}$} & \multirow{2}{*}{$\begin{array}{l}\text { Mass of steel } \\
\text { produced } \\
\text { (t) }\end{array}$} & \multirow{2}{*}{$\begin{array}{l}\text { Specific } \\
\text { energy } \\
(\mathrm{GJ} / \mathrm{t})\end{array}$} & \multirow[t]{2}{*}{ Steel type } \\
\hline & $\begin{array}{l}\text { On, } \\
\text { unloaded }\end{array}$ & $\begin{array}{l}\text { On, } \\
\text { loaded }\end{array}$ & $\begin{array}{l}\text { Off, } \\
\text { unloaded }\end{array}$ & & & & & \\
\hline 2282951 & 84 & 112 & 28 & 288.4 & 129 & 94.5 & 1.366 & $5140 \mathrm{HM}$ \\
\hline 2282952 & 82 & 103 & 21 & 324.8 & 133 & 95.5 & 1.391 & $9322 \mathrm{~A}$ \\
\hline 2282953 & 82 & 101 & 19 & 285.7 & 136 & 95.5 & 1.423 & $9325 \mathrm{~A}$ \\
\hline 2282954 & 75 & 102 & 27 & 333.9 & 124 & 93.9 & 1.323 & 1540HQ \\
\hline 2282955 & 78 & 104 & 26 & 319.0 & 129 & 93.7 & 1.374 & 1548HA \\
\hline 2282958 & 82 & 104 & 22 & 287.9 & 131 & 92.3 & 1.420 & VC9 \\
\hline 2282959 & 80 & 109 & 29 & 291.7 & 129 & 95.3 & 1.349 & 1548HA \\
\hline 2282961 & 83 & 102 & 19 & 304.4 & 131 & 91.4 & 1.434 & 15B35HD \\
\hline 2282962 & 83 & 106 & 23 & 333.6 & 132 & 95.3 & 1.383 & 1548HA \\
\hline 2282963 & 83 & 109 & 26 & 351.3 & 130 & 97.0 & 1.340 & $5120 \mathrm{HB}$ \\
\hline 2282966 & 85 & 109 & 24 & 320.8 & 142 & 97.7 & 1.455 & $5135 \mathrm{HA}$ \\
\hline 2282972 & 84 & 100 & 16 & 310.6 & 135 & 94.7 & 1.422 & $15 \mathrm{~V} 15 \mathrm{HF}$ \\
\hline 2282975 & 76 & 99 & 23 & 296.9 & 124 & 94.8 & 1.308 & 1548HA \\
\hline Average & 81.3 & 104.6 & 23.3 & 311.8 & 131 & 94.7 & 1.383 & - \\
\hline
\end{tabular}

(a) ${ }_{500}$

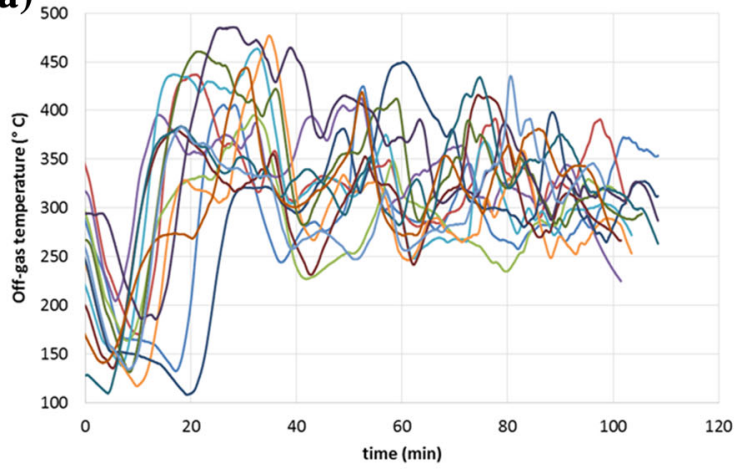

Fig. 4 Off-gas temperature profile: a for each batch; $\mathbf{b}$ average profile

\section{Methodology}

\subsection{Cogeneration plant conceptualization}

The concept of the bottoming cogeneration plant is to recover the heat of the dedusting system to generate superheated steam to drive a condensation turbine and to feed the ejectors of the degassing system, as shown in Fig. 5. Heat recovery should take place in the primary line of the dedusting system, between the combustion chamber and the heat exchanger. The off-gas temperature is measured here, and is the highest at this place. A thermal reservoir (TR) is placed right after the combustion chamber in order to damp the EAF transient operation evinced in Fig. 4. When the off-gas temperature exceeds the TR temperature, the gas stream transfers heat to the reservoir; (b)

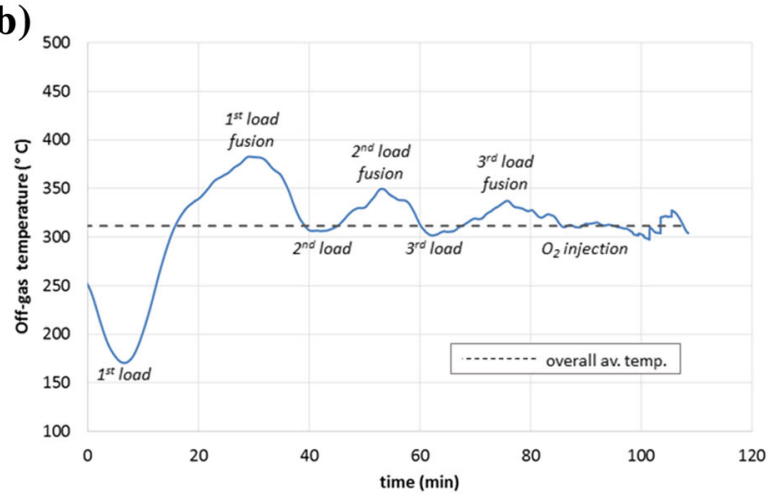

otherwise, TR transfers heat to the gas stream. After leaving the TR, the off-gas enters a heat recovery steam generator (HRSG), where superheated steam is generated. To keep the mini-mill operation flexible, the cogeneration plant should operate in parallel with the existing natural gas-fired boilers. Furthermore, if the cogeneration plant needs to be shut down for any reason, TR and HRSG can be bypassed to keep the mini-mill working. In this situation, the gas-fired boilers should meet the steam demand. The design parameters adopted for the cogeneration plant are shown in Table 2.

Regarding the thermal reservoir design, it is considered to be built with stainless steel tubes filled with a mixture of $60 \% \mathrm{NaNO}_{3}$ (mass basis) and $40 \% \mathrm{KNO}_{3}$. In this proportion, the salt mixture melts at $220{ }^{\circ} \mathrm{C}$, remains in two-phase (solid-liquid) state up to $240{ }^{\circ} \mathrm{C}$ and boils at $550{ }^{\circ} \mathrm{C}$. It 


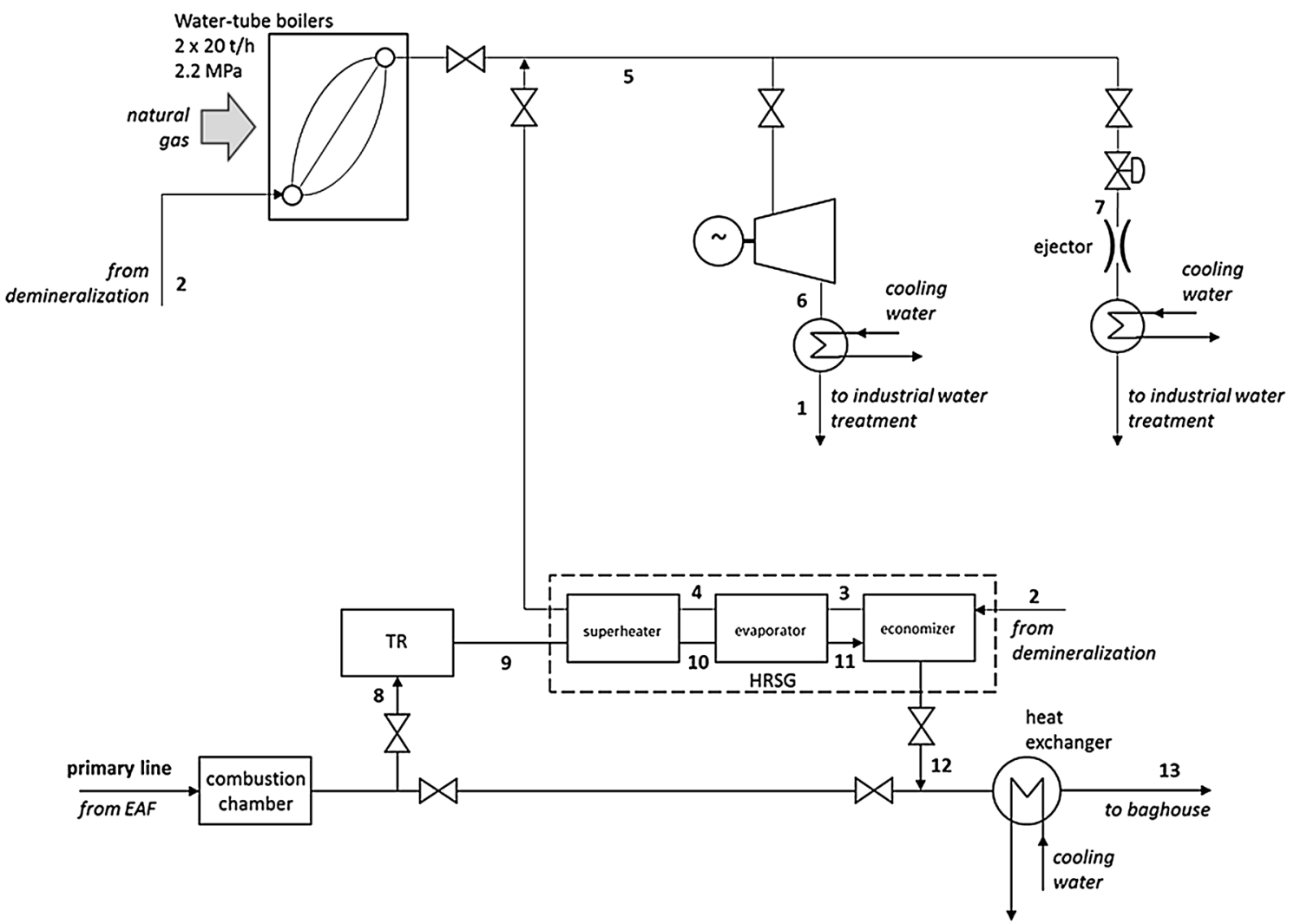

Fig. 5 Concept of the bottoming cogeneration plant

Table 2 Design parameters of the cogeneration plant

\begin{tabular}{llll}
\hline Point (Fig. 5) & Description & Adopted values & Note \\
\hline 1 & Condenser outlet & $P_{1}=50 \mathrm{kPa} ; T_{1}=45{ }^{\circ} \mathrm{C}$ & To approximately match the demineralized water state \\
5 & Turbine inlet & $P_{5}=2.2 \mathrm{MPa} ; T_{5}=300{ }^{\circ} \mathrm{C}$ & To match the existing boiler pressure \\
6 & Turbine outlet & $P_{6}=50 \mathrm{kPa}$ & Typically adopted to assure a proper turbine operation \\
7 & Ejector inlet & $P_{7}=1.5 \mathrm{MPa}$ & Actual process requirement, mass flow up to 20 t/h \\
8 & TR off-gas inlet & $\dot{m}_{8}=\dot{m}_{\mathrm{g}}=91.54 \mathrm{~kg} / \mathrm{s}$ & Actual off-gas flow \\
9 & HRSG off-gas inlet & $T_{9}=311.8{ }^{\circ} \mathrm{C}$ & Average off-gas temperature (see Sect. 2) \\
12 & HRSG off-gas outlet & $T_{12} \geq 130{ }^{\circ} \mathrm{C}$ & To avoid acid condensation \\
13 & Baghouse off-gas inlet & $T_{13} \leq 130{ }^{\circ} \mathrm{C}$ & To avoid fire in the baghouse \\
\hline
\end{tabular}

presents specific heat equal to $1.5 \mathrm{~kJ} / \mathrm{kgK}$ and specific mass equal to $1800 \mathrm{~kg} / \mathrm{m}^{3}$ [13]. The TR preliminary design resembles a shell-and-tube heat exchanger without baffles, with the off-gas flowing parallel to the tube's orientation, as shown in Fig. 6. The length of $25 \mathrm{~m}$ is chosen to fit the available space in the mini-mill. The mass of salt mixture within the TR tubes should be enough to keep the salt mixture completely liquid during the EAF operation.

\subsection{Thermal reservoir design}

A lumped thermodynamic model is proposed to calculate the required mass of salt in the TR and its temporal temperature profile. This model is justified because the TR geometry is not fully defined during the basic thermal design, so that it is not possible to take into account heat transfer coefficients that are dependent on the geometry. For the thermodynamic model, it is considered that:

i. TR is adiabatic and damps the off-gas transient temperature to the average value, so that the off-gas temperature in the TR outlet (point 9 in Fig. 5) is $T_{9}=311.8^{\circ} \mathrm{C}$;

ii. During the lumped period $\Delta t_{\mathrm{h}}$ on which the off-gas are hotter than the salt, the average temperature in the TR inlet (point 8 in Fig. 5) is $\bar{T}_{8, \mathrm{~h}}=336.1^{\circ} \mathrm{C}$; 


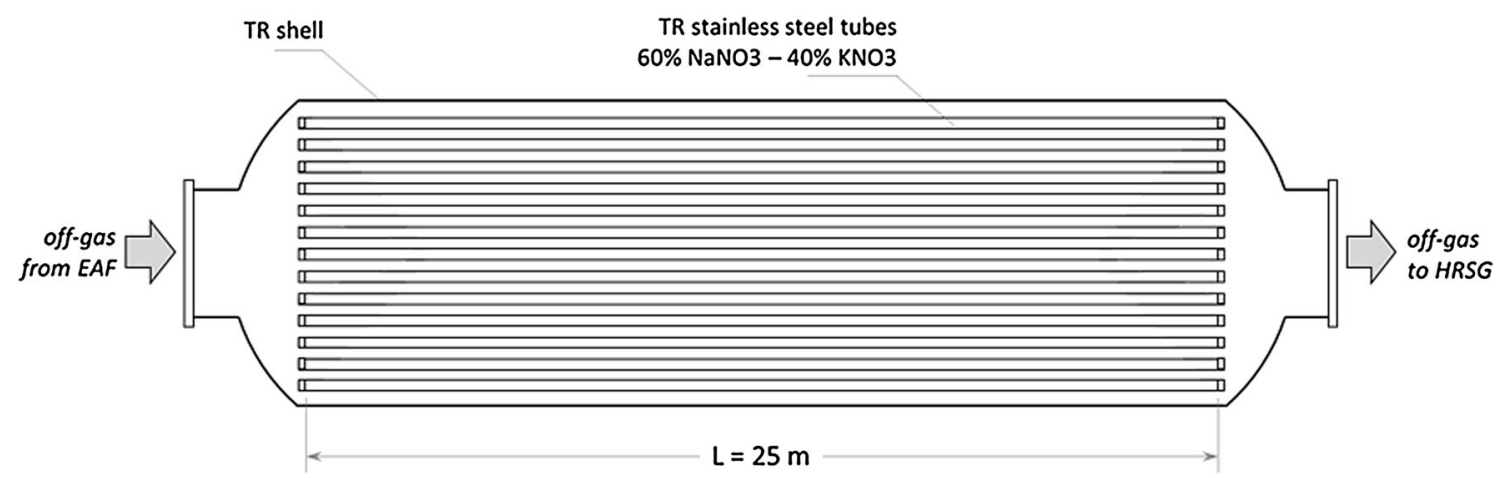

Fig. 6 Thermal reservoir design

iii. During the period $\Delta t_{c}$ on which the off-gas are colder than the salt, the average temperature in the TR inlet is $\bar{T}_{8, \mathrm{c}}=273.8^{\circ} \mathrm{C}$;

iv. The salt temperature varies between $T_{\mathrm{s}, \min }=T_{9}$ and $T_{\mathrm{s}, \max }=\bar{T}_{8, \mathrm{~h}}$, and also the salt properties are constant.

During period $\Delta t_{\mathrm{h}}$, the off-gas enters the TR with temperature $\bar{T}_{8, \mathrm{~h}}$ and leaves it with temperature $T_{9}$, resulting in a heat transfer rate calculated according to Eq. 1, on which $\dot{m}_{\mathrm{g}}=\dot{m}_{8}=\dot{m}_{9}$

$q_{\mathrm{g}, \mathrm{TR}}=\dot{m}_{\mathrm{g}} c_{\mathrm{p}, \mathrm{g}}\left(\bar{T}_{8, \mathrm{~h}}-T_{9}\right)$.

The off-gas heat is transferred to the salt, so that it requires the time interval $\Delta t_{\mathrm{h}}$ to increase the salt mass temperature from $T_{\text {sl,min }}$ to $T_{\text {sl,max }}$. Thus, the required mass is calculated according to Eq. 2:

$m_{\mathrm{sl}}=\frac{q_{\mathrm{g}, \mathrm{TR}} \Delta t_{\mathrm{h}}}{c_{\mathrm{p}, \mathrm{sl}}\left(T_{\mathrm{sl}, \mathrm{max}}-T_{\mathrm{sl}, \text { min }}\right)}=\frac{\dot{m}_{\mathrm{g}} c_{\mathrm{p}, \mathrm{g}} \Delta t_{\mathrm{h}}}{c_{\mathrm{p}, \mathrm{sl}}}$.

Of course, the mass of salt could be alternatively calculated for the period $\Delta t_{\mathrm{c}}$ on which the off-gas enters the TR with temperature $\bar{T}_{8, \mathrm{c}}$. Knowing the mass of salt, the number of tubes required for the TR is calculated according to Eq. 3. From the mass salt and the actual off-gas temperature profile (Fig. 4), the salt temperature profile can be numerically determined by applying Eq. 4 to every instant $t_{\mathrm{k}}$, assuming that at $t_{0}, T_{\mathrm{sl}, 0}=T_{\mathrm{s}, \max }$,

$N_{\mathrm{t}}=\frac{4 m_{\mathrm{sl}}}{\pi D_{\mathrm{t}}^{2} L \rho_{\mathrm{sl}}}$,

$T_{\mathrm{sl}, \mathrm{k}}=T_{\mathrm{sl}, \mathrm{k}-1}+\frac{\dot{m}_{\mathrm{g}} c_{\mathrm{p}, \mathrm{g}}\left[T_{8, \mathrm{k}}-T_{9}\right]}{m_{\mathrm{sl}} c_{\mathrm{p}, \mathrm{sl}}}\left(t_{\mathrm{k}}-t_{\mathrm{k}-1}\right)$

\subsection{Cogeneration design}

Basically, the cogeneration plant is sized by applying mass and energy balances to each component of the plant (Eqs. 5-6, respectively), under the following hypothesis: i. There is steady state, since the TR damps the transient effects from the EAF;

ii. The off-gas properties are constant;

iii. The efficiencies are considered for HRSG, steam turbine, power generator and pump;

iv. Any pressure drop and heat losses in pipes and valves are neglected;

$\sum \dot{m}_{\mathrm{i}}=\sum \dot{m}_{\mathrm{o}}$

$q-\dot{W}=\sum \dot{m}_{\mathrm{o}} h_{\mathrm{o}}-\sum \dot{m}_{\mathrm{i}} h_{\mathrm{i}}$.

Application of Eqs. 5-6 to each component is detailed as follows.

\subsubsection{HRSG}

The HRSG is divided into three sections: superheater, evaporator and economizer. According to Lora and Nascimento [13], heat loss to ambient can be reduced up to $3 \%$ of the energy input. Based on this, an efficiency of $\eta_{\mathrm{sg}}=0.97$ in each section of this component is admitted. For the off-gas stream, Eq. 5 is $\dot{m}_{\mathrm{g}}=\dot{m}_{9}=\dot{m}_{10}=\dot{m}_{11}=\dot{m}_{12}$; for the steam one, it is $\dot{m}_{\mathrm{st}}=$ $\dot{m}_{2}=\dot{m}_{3}=\dot{m}_{4}=\dot{m}_{5}$. Provided the pinch point $\Delta T_{\mathrm{pp}}$ (Eq. 7), steam flow is calculated from an energy balance on the superheater (Eq. 8). A proper choice of the pinch point assures the best trade-off between heat recovery and offgas temperature in the outlet.

$\Delta T_{\mathrm{pp}}=T_{10}-T_{4}=T_{9}-T_{\text {sat }}\left(P_{5}\right)$,

$\dot{m}_{\mathrm{st}}=\frac{\eta_{\mathrm{sg}} \dot{m}_{\mathrm{g}} c_{\mathrm{p}, \mathrm{g}}\left(T_{9}-T_{10}\right)}{h_{5}-h_{4}}$.

In a similar way, off-gas temperature leaving the evaporator is calculated from an energy balance (Eq. 9), provided the approach point $\Delta T_{\text {ap }}$ (Eq. 10). The approach point assures that no evaporation occurs in the economizer. Finally, the HRSG outlet temperature results from the energy balance on the economizer (Eq. 11). 


$$
\begin{aligned}
& T_{11}=T_{10}-\frac{\dot{m}_{\mathrm{st}}\left(h_{4}-h_{3}\right)}{\eta_{\mathrm{sg}} \dot{m}_{\mathrm{g}} c_{\mathrm{p}, \mathrm{g}}} \\
& \Delta T_{\mathrm{ap}}=T_{4}-T_{3}=T_{\mathrm{sat}}\left(P_{5}\right)-T_{3}, \\
& T_{12}=T_{11}-\frac{\dot{m}_{\mathrm{st}}\left(h_{3}-h_{2}\right)}{\eta_{\mathrm{sg}} \dot{m}_{\mathrm{g}} c_{\mathrm{p}, \mathrm{g}}}
\end{aligned}
$$

\subsubsection{Condensing turbine}

The actual enthalpy in the turbine outlet is calculated from an isentropic efficiency $\eta_{\mathrm{t}}=0.7$ [14], as shown in Eq. 12 . The power output is then calculated from the energy balance expressed in Eq. 13, taking into account the power generator efficiency $\eta_{\mathrm{g}}=0.95$.

$$
\begin{aligned}
& h_{6}=h_{5}-\eta_{\mathrm{t}}\left[h_{3}-h\left(P_{6}, s_{5}\right)\right], \\
& \dot{W}_{\mathrm{e}}=\eta_{\mathrm{g}} \dot{m}_{\mathrm{st}}\left(h_{5}-h_{6}\right) .
\end{aligned}
$$

\subsubsection{Condenser}

The thermodynamic state of the indusial water treatment is considered approximately the same as the steam leaving the condenser, so that the heat rejected on it is calculated as shown in Eq. 14. Knowing the difference of temperature of the cooling water $\Delta T_{\mathrm{cw}}$ and adopting a specific heat constant for liquid water $c_{\mathrm{p}, \mathrm{cw}}=4.182 \mathrm{~kJ} / \mathrm{kgK}$, the cooling water flow in the condenser is calculated from Eq. 15.

$q_{\mathrm{c}}=\dot{m}_{\mathrm{st}}\left(h_{6}-h_{1}\right)$,
$\dot{m}_{\mathrm{cw}, \mathrm{c}}=\frac{q_{\mathrm{c}}}{c_{\mathrm{p}, \mathrm{cw}} \Delta T_{\mathrm{cw}}}$.

\subsubsection{Pump}

Similarly to the turbine, an isentropic pumping efficiency $\eta_{\mathrm{p}}=0.8$ [14] is considered to calculate the actual enthalpy in the pump outlet, as shown in Eq. 16. The required pumping power is calculated according to Eq. 17.

$h_{2}=h_{1}+\frac{h\left(P_{2}, s_{1}\right)-h_{1}}{\eta_{\mathrm{p}}}$,
$\dot{W}_{\mathrm{p}}=\dot{m}_{\mathrm{st}}\left(h_{2}-h_{1}\right)$.

\subsubsection{Heat exchanger}

To be safely filtered in the baghouse, the off-gas temperature should not exceed $T_{13}=130^{\circ} \mathrm{C}$. Depending on the HRSG off-gas outlet temperature $T_{12}$, further cooling in the heat exchanger downstream the HRSG could be necessary.
Similarly to Eq. 13, the cooling water flow in the heat exchanger is calculated from an energy balance (Eq. 18):

$\dot{m}_{\mathrm{cw}, \mathrm{he}}=\frac{\dot{m}_{\mathrm{g}} c_{\mathrm{p}, \mathrm{g}}\left(T_{12}-T_{13}\right)}{c_{\mathrm{p}, \mathrm{cw}} \Delta T_{\mathrm{cw}}}$.

\subsection{Economic analysis}

The economic analysis is based on equations for investment cost of the plant components found in Santos [15], except for the investment cost of the thermal reservoir, which is calculated based on premises adopted by Gaggioli et al. [12]. Equations for specific costs of electric energy and steam are adapted from Vilela [16]. The main economic parameters adopted are shown in Table 3.

The investment cost for steam turbine (with generator), HRSG, condenser and pump are given in Eqs. 19-22 [15], respectively. In these equations, the units for power is $\mathrm{kW}$; for temperature ${ }^{\circ} \mathrm{C}$; for mass flow $\mathrm{kg} / \mathrm{s}$; and for enthalpy $\mathrm{kJ} /$ kg:

$I_{\mathrm{t}}=59.495 \dot{W}_{\mathrm{e}}^{0.70}\left[1+\left(\frac{1-0.95}{1-\eta_{\mathrm{t}}}\right)^{3}\right]\left[1+5\left(\frac{T_{5}-86.6}{10.42}\right)\right]$,

$I_{\mathrm{sg}}=4745\left[\frac{h_{5}}{\log _{10}\left(T_{9}-T_{12}\right)}\right]^{0.8}+11820 \dot{m}_{\mathrm{st}}+658 \dot{m}_{\mathrm{g}}$,

$I_{\mathrm{c}}=1773 \dot{m}_{\mathrm{st}}$,

$I_{\mathrm{p}}=4991.4 \dot{W}_{\mathrm{p}}^{0.71}\left[1+\left(\frac{1-0.80}{1-\eta_{\mathrm{p}}}\right)^{3}\right]$.

The investment cost of the thermal reservoir is calculated considering unitary costs (USD/ $\mathrm{kg}_{\mathrm{sl}}$ ) adapted from Gaggioli et al. [12], except for the tubes cost, which is adjusted with actual market prices. The detailed costs of the TR are shown in Table 4, resulting then in Eq. 23:

$I_{\mathrm{tr}}=5.63 m_{\mathrm{sl}}+8583 N_{\mathrm{t}}^{0.4997}$.

The equations for specific costs of electric energy and steam found in Vilela [16] require an annuity factor $f$ that takes into account the annual interest rate $j$ (expressed as decimal, not percentage) and plant useful life $k$ (in years), as shown in Eq. 24:

$f=\frac{j(1+j)^{\mathrm{k}}}{(1+j)^{\mathrm{k}}-1}$.

Regarding the electric energy specific cost (USD/MWh), it depends on which steam stream drives the turbine. Here, the turbine is driven by the steam provided by the HRSG, so that the specific cost is given in Eq. 25 (adapted from 
Table 3 Parameters adopted for economic analysis (1 USD = $3.40 \mathrm{BRL})$

\begin{tabular}{lll}
\hline Description & Adopted value & Note \\
\hline Electric energy cost $\left(C_{\mathrm{e}}\right)$ & $59.12 \mathrm{USD} / \mathrm{MWh}$ & Actual value of the mini-mill in 2016 \\
Cost of nat. gas $\left(C_{\mathrm{ng}}\right)$ & $0.28 \mathrm{USD} / \mathrm{m}^{3}$ & Actual value of the mini-mill in 2016 \\
Cost of cooling water $\left(C_{\mathrm{cw}}\right)$ & $1.00 \mathrm{USD} / \mathrm{m}^{3}$ & Actual value of the mini-mill in 2016 \\
Cogeneration O\&M cost $\left(C_{\mathrm{om}, \mathrm{cg}}\right)$ & $15 \mathrm{USD} / \mathrm{MWh}$ & According to Vilela [16] \\
Existing boiler O\&M cost $\left(C_{\mathrm{om}, \mathrm{b}}\right)$ & $5 \mathrm{USD} / \mathrm{MWh}$ & Actual value of the mini-mill in 2016 \\
Annual operating time $(H)$ & $7920 \mathrm{~h}$ & According mini-mill maintenance schedule \\
Cogen. plant useful life $(k)$ & 15 years & Stipulated \\
Annual interest rate $(j)$ & $12 \%$ & Stipulated \\
\hline
\end{tabular}

Table 4 Detailed TR costs

\begin{tabular}{lll}
\hline Description & Adopted value & Note \\
\hline Shell & $1.32 \mathrm{USD} / \mathrm{kg}_{\mathrm{sl}}$ & Adapted from [12] \\
Foundation & $4.16 \mathrm{USD} / \mathrm{kg}_{\mathrm{sl}}$ & Adapted from [12] \\
Insulation & $0.15 \mathrm{USD} / \mathrm{kg}_{\mathrm{sl}}$ & Adapted from [12] \\
Tubes & - & Last term of Eq. 19 \\
\hline
\end{tabular}

[16]). In this equation, it is considered that the investments required are the turbine and the condenser. Also, units of power, annual operating time and O\&M cost are MW, $h$ and USD/MWh, respectively:

$C_{\mathrm{e}, \mathrm{cg}}=\frac{f\left(I_{\mathrm{t}}+I_{\mathrm{c}}\right)}{H \dot{W}_{\mathrm{e}}}+\frac{C_{\mathrm{om}, \mathrm{cg}}\left(I_{\mathrm{t}}+I_{\mathrm{c}}\right)}{\sum_{\mathrm{i}} I_{\mathrm{i}}}$.

For the steam specific cost (USD/MWh) generated in the HRSG, it is considered that the investments required are the HRSG, pump and TR (Eq. 26, adapted from [16]). For the steam generated in the existing boilers, the specific cost is shown in Eq. 27. In this equation, the annuity factor and investments are not considered because the boilers are already amortized. Note that in Eqs. 25 and 26, the cogeneration O\&M cost is split proportionally to the respective investments.

$C_{\mathrm{st}, \mathrm{sg}}=\frac{f\left(I_{\mathrm{sg}}+I_{\mathrm{p}}+I_{\mathrm{tr}}\right)}{H \dot{m}_{\mathrm{st}}\left(h_{5}-h_{2}\right)}+\frac{C_{\mathrm{om}, \mathrm{cg}}\left(I_{\mathrm{sg}}+I_{\mathrm{p}}+I_{\mathrm{tr}}\right)}{\sum_{\mathrm{i}} I_{\mathrm{i}}}$,

$C_{\mathrm{st}, \mathrm{b}}=\frac{C_{\mathrm{ng}}}{\eta_{\mathrm{b}} \mathrm{LHV}}+C_{\mathrm{om}, \mathrm{b}}$.

The current annual expenses of the EAF and the ones of the EAF with cogeneration are calculated through Eq. 28. The respective expenses $E_{\mathrm{i}, \mathrm{j}}$ for this equation are shown in Table 5. It should be noted that the expenses with steam are considered over half of the annual operating time $H$, because the degassing process demands steam only approximately $30 \mathrm{~min} / \mathrm{h}$ (see Sect. 2 ). A steam bypass ratio $b_{\mathrm{p}}$ is also taken into account for this expense and the reason for that is explained later in Sect. 4.2. The cooling water expense is basically the cost of make-up water to compensate evaporation in the cooling tower, which is quantified through an evaporation ratio $r_{\mathrm{ev}}$. The net annual revenue is the difference between the expenses (Eq. 29) that are used to calculate the payback period (Eq. 30).

$E_{\mathrm{i}}=\sum_{\mathrm{j}} E_{\mathrm{i}, \mathrm{j}}$

$R=E_{\mathrm{cur}}-E_{\mathrm{cg}}$,

$p b=\sum I / R$.

\section{Results}

\subsection{Thermal reservoir}

For the given off-gas temperature profile, the TR accumulates heat during $3978 \mathrm{~s}$ and releases heat during $2531 \mathrm{~s}$ to provide $91.536 \mathrm{~kg} / \mathrm{s}$ of off-gas at $311.8^{\circ} \mathrm{C}$ to the HRSG. Thus, the required mass of salt in the TR is $248,448 \mathrm{~kg}$, which corresponds to a volume equal to $138 \mathrm{~m}^{3}$. This amount of salt results in a heat storage capacity of 9018.7 MJ. The maximum temperature of the salt is $336.3{ }^{\circ} \mathrm{C}$ at approximately $95 \mathrm{~min}$ of EAF operation; the minimum one is $313.9{ }^{\circ} \mathrm{C}$ at $16 \mathrm{~min}$. The salt is stored into 77 stainless steel $12^{\prime \prime}$ tubes, schedule 40 , each tube with $25 \mathrm{~m}$ length. This is a commercially available tube with internal diameter equal to $303.23 \mathrm{~mm}\left(11.938^{\prime \prime}\right)$. The temperature profile of the salt, along with the off-gas temperature profile, is shown in Fig. 7. It is interesting to note that when the TR transfers heat to the off-gas, $d T_{\text {sl }} / d t<0$ for every instant on which $T_{8}<T_{9}$. Conversely, when the TR stores heat from the off-gas, $d T_{\mathrm{sl}} / d t>0$ for every instant on which $T_{8}>T_{9}$. On every instant when $T_{8}=T_{9}$, the slope changes, i.e., $\mathrm{d} T_{\mathrm{sl}} / \mathrm{d} t=0$. That is quite clearly depicted in Fig. 7 for $t \cong 16 \mathrm{~min}$ and $t \cong 60 \mathrm{~min}$. It can also be easily proved by rearranging Eq. 4 as Eq. 31: it is positive when $T_{8}>T_{9}$, negative when $T_{8}<T_{9}$ and zero for $T_{8}=T_{9}$. 
Table 5 Expenses with power, steam and cooling water in each situation

\begin{tabular}{lllll}
\hline$j$ & Expense & Current situation $(i=$ cur $)$ & With cogeneration $(i=\mathrm{cg})$ & \\
\cline { 4 - 5 } & & & Ejectors off & Ejectors on \\
\hline Power & $E_{\mathrm{i}, \mathrm{p}}$ & $\dot{W}_{\mathrm{e}, \mathrm{EAF}} H C_{\mathrm{e}}$ & $\left(\dot{W}_{\mathrm{e}, \mathrm{EAF}}-\dot{W}_{\mathrm{e}, \mathrm{cg}}^{\text {off }}\right) \frac{H}{2} C_{\mathrm{e}}+\dot{W}_{\mathrm{e}, \mathrm{cg}}^{\text {off }} \frac{H}{2} C_{\mathrm{e}, \mathrm{cg}}$ & $\left(\dot{W}_{\mathrm{e}, \mathrm{EAF}}-\dot{W}_{\mathrm{e}, \mathrm{cg}}^{\text {on }}\right) \frac{H}{2} C_{\mathrm{e}}+\dot{W}_{\mathrm{e}, \mathrm{cg}} \frac{H}{2} C_{\mathrm{e}, \mathrm{cg}}$ \\
Steam & $E_{\mathrm{i}, \mathrm{st}}$ & $\dot{m}_{\mathrm{st}, \mathrm{d}}\left(h_{5}-h_{2}\right) \frac{H}{2} C_{\mathrm{st}, \mathrm{b}}$ & - & $\left(h_{5}-h_{2}\right) \frac{H}{2}\left[\left(\dot{m}_{\mathrm{st}, \mathrm{d}}-b_{\mathrm{p}} \dot{m}_{\mathrm{st}}\right) C_{\mathrm{st}, \mathrm{b}}+b_{\mathrm{p}} \dot{m}_{\mathrm{st}} C_{\mathrm{st}, \mathrm{sg}}\right]$ \\
Cooling water & $E_{\mathrm{i}, \mathrm{cw}}$ & $r_{\mathrm{ev}}\left(\dot{m}_{\mathrm{cw}, \mathrm{he}} / \rho_{\mathrm{w}}\right) H C_{\mathrm{cw}}$ & $r_{\mathrm{ev}}\left[\left(\dot{m}_{\mathrm{cw}, \mathrm{he}}^{\mathrm{cg}}+\dot{m}_{\mathrm{cw}, \mathrm{c}}^{\text {off }}\right) / \rho_{\mathrm{w}}\right] \frac{H}{2} C_{\mathrm{cw}}$ & $r_{\mathrm{ev}}\left[\left(\dot{m}_{\mathrm{cw}, \mathrm{he}}^{\mathrm{cg}}+\dot{m}_{\mathrm{cw}, \mathrm{c}}^{\text {on }}\right) / \rho_{\mathrm{w}}\right] \frac{H}{2} C_{\mathrm{cw}}$ \\
\hline
\end{tabular}

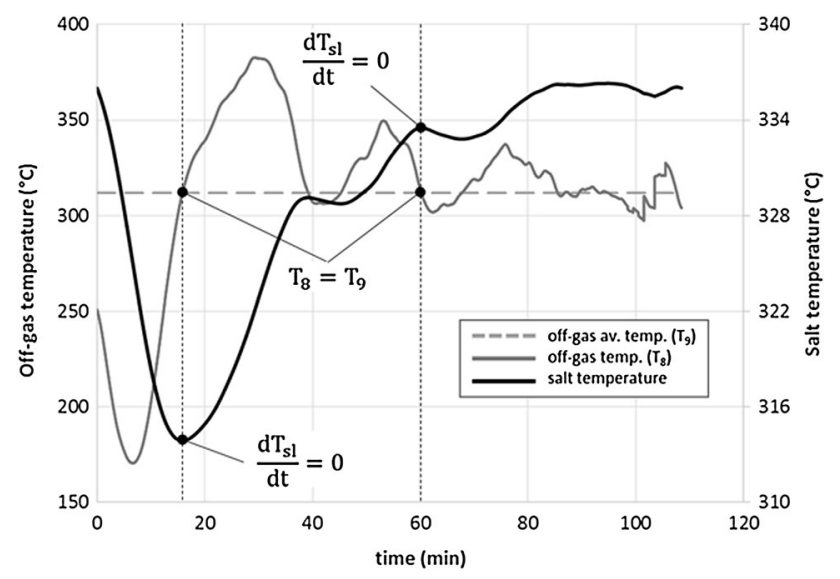

Fig. 7 Temperature profile of the salt (TR)

$$
\frac{\mathrm{d} T_{\mathrm{sl}}}{\mathrm{d} t}=\lim _{\Delta t \rightarrow 0} \frac{\Delta T_{\mathrm{sl}}}{\Delta t}=\frac{\dot{m}_{\mathrm{g}} c_{\mathrm{p}, \mathrm{g}}}{m_{\mathrm{sl}} c_{\mathrm{p}, \mathrm{sl}}}\left(T_{8}-T_{9}\right) .
$$

\subsection{Cogeneration plant}

The results for each point of the cogeneration plant depicted in Fig. 5 are shown in Table 6. The approach point is set to $10{ }^{\circ} \mathrm{C}$ and the pinch point is adjusted to $10^{\circ} \mathrm{C}$ to result in an HRSG off-gas outlet temperature of $T_{12}=199.8^{\circ} \mathrm{C}$. The temperature profile of the HRSG is shown in Fig. 8. The other results are summarized as follows:

Heat $\quad q_{\mathrm{g}}=10491.5 \mathrm{~kW}$.

recovered

from

off-gas in

Superheater:

$q_{\mathrm{g}, \mathrm{sh}}=806.9 \mathrm{~kW}$.

the HRSG:

Evaporator: $\quad q_{\mathrm{g}, \mathrm{ev}}=7106.3 \mathrm{~kW}$.

Economizer: $\quad q_{\mathrm{g}, \mathrm{ec}}=2578.3 \mathrm{~kW}$.

Heat transferred to generate steam in the HRSG:
Heat loss in the HRSG:

Steam flow produced by the HRSG:

Power generated in the turbine:

Heat transferred in the condenser:

Power required by the pump:

Cycle efficiency ${ }^{1}$ :

The operation of the steam turbine, pump and condenser depends on the operation of the degassing process. During 30 min when there is no steam demand for degassing, the turbine operates at its rated capacity $\dot{W}_{\mathrm{e}}=1634.1 \mathrm{~kW}$ and the condenser transfers $q_{\mathrm{c}}=8465.5 \mathrm{~kW}$. During the other $30 \mathrm{~min}$, the ejectors of the degassing process require steam, so that part of the steam generated in the HRSG is diverted from the turbine to the ejectors. However, a minimum steam flow should keep driving the turbine. Based on the condensing turbine typical performance map shown in Fig. 9 [17], the minimum flow in the steam turbine adopted in this work is $30 \%$ of the nominal flow, which results in a bypass ratio of $b_{\mathrm{p}}=0.7$. Thus, only $2.520 \mathrm{~kg} / \mathrm{s}$ of steam generated in the HRSG can be diverted from the turbine to meet the degassing process $\left(\dot{m}_{\mathrm{st}, \mathrm{d}}=5.556 \mathrm{~kg} / \mathrm{s}\right)$; the difference of $3.036 \mathrm{~kg} / \mathrm{s}$ should be provided by the existing boilers. The need for cooling water in both condenser and heat exchanger is calculated considering a typical difference of temperature $\Delta T_{\mathrm{cw}}=5^{\circ} \mathrm{C}$. Cooling in the heat exchanger downstream the HRSG is necessary because the HRSG off-gas outlet temperature $T_{12}=199.8^{\circ} \mathrm{C}$ is still high to be safely filtered in the baghouse. Without the cogeneration plant, the water flow required in the heat exchanger is $\dot{m}_{\mathrm{cw}, \mathrm{he}}=814.21 \mathrm{~kg} / \mathrm{s}$. It should be noted that the operation of TR, HRSG and heat exchanger does not depend on the degassing process operation. Table 7 summarizes the plant operation against the degassing process operation.

$$
\left.\overline{{ }^{1} \eta_{\mathrm{cl}}=\left(\dot{W}_{\mathrm{e}}\right.}-\dot{W}_{\mathrm{p}}\right) / q_{\mathrm{g}}
$$


Table 6 Results for each point of the cogeneration plant

\begin{tabular}{lllllll}
\hline Point (Fig. 5) & $\dot{m}(\mathrm{~kg} / \mathrm{s})$ & $T\left({ }^{\circ} \mathrm{C}\right)$ & $P(\mathrm{kPa})$ & $\mathrm{h}(\mathrm{kJ} / \mathrm{kg})$ & $\mathrm{s}(\mathrm{kJ} / \mathrm{kgK})$ & $X$ \\
\hline 1 & 3.600 & 45.0 & 50 & 188.47 & 0.6386 & Comp. liq. \\
2 & 3.600 & 45.1 & 2200 & 190.93 & 0.6395 & Comp. liq. \\
3 & 3.600 & 207.3 & 2200 & 885.58 & 2.399 & Comp. liq. \\
4 & 3.600 & 217.3 & 2200 & 2800.2 & 6.304 & 1.000 \\
5 & 3.600 & 300.0 & 2200 & 3017.6 & 6.717 & Sup. steam \\
6 & 3.600 & 81.3 & 50 & 2538.8 & 7.295 & 0.954 \\
7 & Up to 5.556 & 286.8 & 1500 & 3017.6 & 6.868 & Sup. steam \\
8 & 91.536 & Variable & - & - & - & Off-gas \\
9 & 91.536 & 311.8 & - & - & - & Off-gas \\
10 & 91.536 & 303.2 & - & - & - & Off-gas \\
11 & 91.536 & 227.3 & - & - & - & Off-gas \\
12 & 91.536 & 199.8 & - & - & - & Off-gas \\
13 & 91.536 & 130.0 & - & - & - & Off-gas \\
\hline
\end{tabular}

\subsection{Economic analysis}

Investment costs required for the plant are shown in Table 8. Considering the data presented in Table 3 , the cost of electric energy generated by the plant is $22.85 \mathrm{USD} / \mathrm{MWh}$ and the cost of the steam generated in the HRSG is $11.24 \mathrm{USD} / \mathrm{MWh}$. The cost of the steam generated by the existing boilers is $36.17 \mathrm{USD} / \mathrm{MWh}$. From these costs, it is possible to calculate the annual expenses of the current situation and the expenses with the cogeneration plant, as shown in Table 9.

From the total investment in Table 8 and the total revenue in Table 9, a payback period equal to 4.06 years is found. The results presented in Tables 8 and 9 are considered the base case for a sensibility analysis. A variation of $+10 \%$ is established in a given parameter of Table 3 (keeping the remaining ones unchanged) to calculate how much it affects the payback period. In addition to the parameters of Table 3, the bypass ratio and total investment are also considered in the sensibility analysis. The sensibility analysis results are shown in Table 10 .

Results from Table 10 show quite clearly that the parameters that most affect the payback period are the total investment $I$, the number of operating hours $H$, the natural gas cost $C_{\mathrm{ng}}$, the bypass ratio $b_{\mathrm{p}}$, the electric energy cost $C_{\mathrm{e}}$ and the O\&M costs for cogeneration $C_{\mathrm{om}, \mathrm{cg}}$, respectively. The TR has a huge impact on the total investment cost and shows quite clearly the influence of transient off-gas temperature on the economic attractiveness.

A range from -20 to $20 \%$ variation on each of these parameters is established to investigate in more detail how each parameter influences the payback, as shown in Fig. 10. The bypass ratio has its maximum value at the base case and it cannot be further increased due to the technical reasons presented in Sect. 4.2. Because of that, it is not depicted in Fig. 10. The operating hours also are 
Table 7 Plant operation against degassing process operation

\begin{tabular}{llc}
\hline Parameter & \multicolumn{2}{l}{ Degassing process operation } \\
\cline { 2 - 3 } & Ejectors off & Ejectors on \\
\hline Steam flow $(\mathrm{kg} / \mathrm{s})$ & & 5.556 \\
Ejectors & 3.600 & 3.600 \\
HRSG & 3.600 & 1.080 \\
Turb./cond. & 0 & 3.036 \\
Boiler & & \\
Cooling water flow $(\mathrm{kg} / \mathrm{s})$ & 404.85 & 121.46 \\
Condenser & 312.47 & 312.47 \\
Heat ex. & 1634.1 & 490.23 \\
Turb. power output $(\mathrm{kW})$ & 8.867 & 13.68 \\
Pump power input $(\mathrm{kW})$ & 1625.2 & 476.55 \\
Plant net power output $(\mathrm{kW})$ & 8465.5 & 2539.7 \\
Cond. heat transfer $(\mathrm{kW})$ & & $10,096.2$ \\
Nat. gas for the boiler ${ }^{\mathrm{a}}$ & 0 & 955.27 \\
Heat $(\mathrm{kW})$ & 0 & \\
Flow $\left(\mathrm{m}^{3} / \mathrm{h}\right)$ & &
\end{tabular}

${ }^{\mathrm{a}} \mathrm{LHV} 38,048 \mathrm{~kJ} / \mathrm{m}^{3} ; \eta_{\mathrm{b}}=0.85$

Table 8 Investment costs

\begin{tabular}{lll}
\hline$i$ & Component & $I_{\mathrm{i}}\left(10^{6} \mathrm{USD}\right)$ \\
\hline 1 & Turbine (with generator) & 1.087 \\
2 & HRSG & 1.727 \\
3 & Condenser & 0.006383 \\
4 & Pump & 0.06396 \\
5 & Thermal reservoir & 1.474 \\
Total & & 4.358 \\
\hline
\end{tabular}

limited to a maximum of $+5 \%$ variation because, otherwise, the EAF maintenance times would be fairly unrealistic. It is interesting to note that two of the most influential parameters ( $H$ and $C_{\mathrm{om}, \mathrm{cg}}$ ) are not subject, to some extent, to external factors and depend only (again, to some extent) on the maintenance team of the mini-mill. If the maintenance team keeps up with the challenge to increase $H$ by $5 \%$ and reduce $C_{\mathrm{om}, \mathrm{cg}}$ by $5 \%$, the payback period would result in 3.78 years. Within the variation limits considered in Fig. 10, the worst scenario would result in a payback period equal to 9.98 years, as long as the most optimistic one would result in 2.31 years.

It is quite rare for Brazilian industries to accept investments with payback period higher than 3 years, so that the cogeneration plant proposed here is not attractive in the base case scenario for the mini-mill considered (it would be attractive in the best case scenario, though). The scale of the plant, irreversibilities and the need to cogenerate power to match the steam demand of the degassing system can be additional factors that affect the economic attractiveness, which must be further investigated. Alternatives that involve heat recovery only for steam generation should also be considered. Further economic and viability analysis should consider scenarios predicting a trend of increasing energy prices in Brazil and long-term energy supply contracts.

It is interesting to note that the payback is not that far from acceptance. As a matter of fact, the OEDC Steel Committee [18] carried out a survey in the steel industry and identified long payback periods as one of the "issues facing companies that are otherwise interested in investing in energy efficiency projects". On the other hand, results were found indicating that "the organizations involved in the survey had a very good awareness of additional benefits, other than energy savings, that could be applied to payback period calculations. However, the evidence obtained also demonstrated that no substantial methodology existed to be able to include the true value of all the relevant benefits in payback period calculations for energy efficiency projects" [18]. In another survey for a different sector [19], it was noted that the "companies are becoming more sophisticated in their energy management. A surprising 69\% use energy efficiency as a risk management tool. Furthermore, many are willing to tolerate long-term

Table 9 Annual expenses with power, steam and cooling water

\begin{tabular}{llrrr}
\hline$j$ & Expense $\left(\times 10^{3}\right.$ USD/year $)$ & Current situation $(i=$ cur $)$ & \multicolumn{2}{c}{ With cogeneration $(i=\mathrm{cg})$} \\
\cline { 3 - 4 } & & & Ejectors off & Ejectors on \\
\hline Power & $E_{\mathrm{i}, \mathrm{p}}$ & $21,070.378$ & $10,301.740$ & $10,466.732$ \\
Steam & $E_{\mathrm{i}, \mathrm{st}}$ & $1,939.135$ & 0 & 301.896 \\
Cooling water & $E_{\mathrm{i}, \mathrm{cw}}^{\mathrm{a}}$ & 232.380 & 102.364 & 703.248 \\
Total & & $23,552.451$ & $10,404.103$ & 61.923 \\
\hline
\end{tabular}

${ }^{\mathrm{a}}$ Evaporation ratio $r_{\mathrm{ev}}=1 \%$ 
Table 10 Sensibility analysis results

\begin{tabular}{|c|c|c|c|c|}
\hline \multirow[t]{2}{*}{ Parameter } & \multicolumn{2}{|c|}{ Parameter values } & \multicolumn{2}{|c|}{ Payback period (base case 4.06 years) } \\
\hline & Base & Varied & Varied & Variation from base case $(\%)$ \\
\hline$C_{\mathrm{e}}(\mathrm{USD} / \mathrm{MWh})$ & 59.12 & 6032 & 3.88 & -4.38 \\
\hline$C_{\mathrm{ng}}\left(\mathrm{USD} / \mathrm{m}^{3}\right)$ & 0.28 & 0.308 & 3.75 & -7.57 \\
\hline$C_{\mathrm{cw}}\left(\mathrm{USD} / \mathrm{m}^{3}\right)$ & 1.00 & 1.10 & 4.04 & -0.49 \\
\hline$C_{\mathrm{om}, \mathrm{cg}}(\mathrm{USD} / \mathrm{MWh})$ & 15 & 16.5 & 4.20 & +3.35 \\
\hline$C_{\mathrm{om}, \mathrm{b}}(\mathrm{USD} / \mathrm{MWh})$ & 5 & 5.5 & 4.01 & -1.30 \\
\hline$H(\mathrm{~h})$ & 7920 & 8712 & 3.64 & -10.3 \\
\hline$k$ (years) & 15 & 16.5 & 4.04 & -0.49 \\
\hline$j(\%)$ & 12 & 13.2 & 4.10 & +0.97 \\
\hline$b_{\mathrm{p}}$ & 0.7 & 0.77 & 3.81 & -6.15 \\
\hline $\mathrm{I}\left(\times 10^{6} \mathrm{USD}\right)$ & 4.358 & 4.777 & 4.52 & +11.2 \\
\hline
\end{tabular}

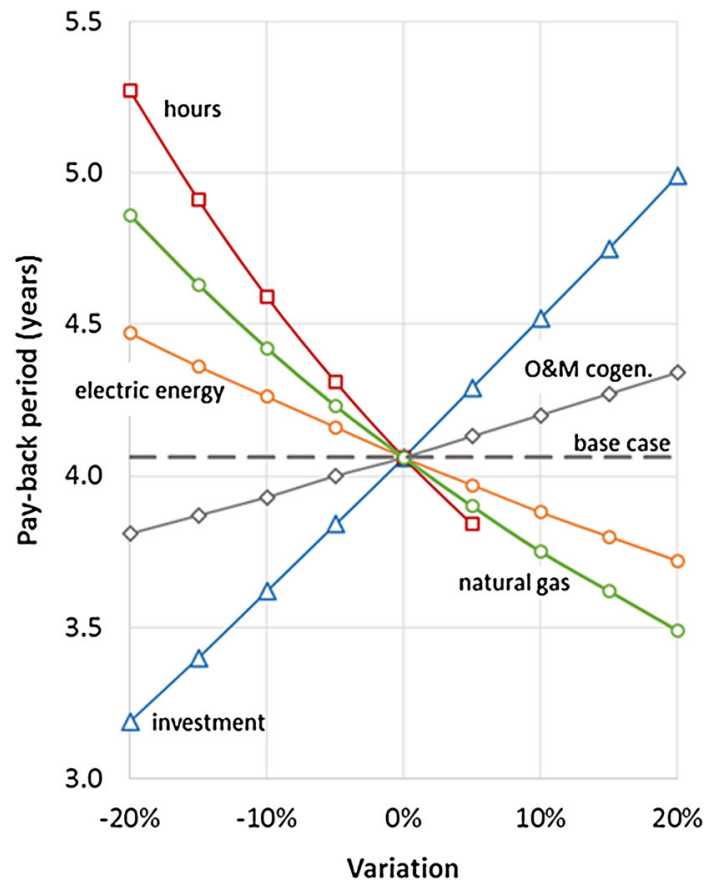

Fig. 10 Influence of the most sensible parameters on the payback period

investments to help achieve greater efficiency: one-half of respondents say that the maximum payback time for energy efficiency investments is 5 years or longer".

\section{Conclusion}

In this paper, a bottoming cogeneration plant was proposed to recover heat from the dedusting system of a Brazilian mini-mill. The actual operational data were considered to calculate the heat available in the off-gas stream and to conceptualize a plant to generate power and superheated steam for the ejectors of the degassing process. Consequently, the off-gas stream would be naturally cooled down by the cogeneration plant, contributing to the reduction in the consumption of water for off-gas cooling upstream the baghouse. To damp the off-gas transient temperature profile and assure a more stable operation of the plant, a thermal reservoir (TR) based on a mixture of two different salts was proposed and sized. Results show that the plant is technically feasible. The TR was able to provide off-gas at constant temperature for the heat recovering steam generator (HRSG). The HRSG is able to provide about half of the steam demanded by the degassing process, so that the remaining demand should be provided by the existing boilers of the mini-mill. The steam turbine operation depends on the degassing process operation and generates more power when the degassing process does not require steam. Even in this case, the power generated is small when compared with the power demand of the electric arc furnace. The consumption of cooling water, on the other hand, presented a significant reduction. From an economic point of view, the costs of the power, steam and cooling water for cogeneration are lower than the actual mini-mill current costs, resulting in a positive revenue. However, the investments required for the plant are very high, so that the revenue generated by the investment would result in a relatively long payback period. A sensibility analysis showed that the most influential parameters in the payback period are total investment, the number of operating hours, the natural gas cost, the electric energy cost and the O\&M costs for cogeneration, respectively. These parameters were varied to establish both worst and best case scenarios. The payback period was found quite shorter in the best case scenario, but significantly higher in the worst case. In the best case scenario, the payback period could be accepted in the Brazilian steel industry, but it is still not short enough to be accepted in the base case. The influence of the scale of the plant, irreversibilities and cogeneration on the economic attractiveness must be further investigated, as well as alternatives that involve heat recovery only for steam 
generation. However, there is a trend to accept higher payback in energy efficiency projects, since recent surveys abroad found in the literature indicate that the companies are aware of the additional benefits, other than energy savings, which could be applied to payback period calculations and many of them are willing to tolerate long-term investments to help achieve greater efficiency.

\section{References}

1. US Environmental Protection Agency (2007) Energy trends in selected manufacturing sectors: opportunities and challenges for environmentally preferable energy outcomes. http://www.tech stuff.com/epa_energy.htm. Accessed Feb 2016

2. Steinparzer T, Haider M, Zauner F, Enickl G, Michele-Naussed M, Horn AC (2013) Electric arc furnace off-gas heat recovery and experience with a testing plant. J Iron Steel Res Int 85(4):519-526. https://doi.org/10.1002/srin.201300228

3. McBrien M, Serrenho AC, Allwood JM (2016) Potential for energy savings by heat recovery in an integrated steel supply chain. Appl Therm Eng 103:592-606. https://doi.org/10.1016/j. applthermaleng.2016.04.099

4. Jouhara H, Almahmoud S, Chauhan A, Delpech B, Nannou T, Tassou SA, Llera R, Lago F, Arribas JJ (2017) Experimental investigation on a flat heat pipe heat exchanger for waste heat recovery in steel industry. Energy Procedia 123:329-334. https:// doi.org/10.1016/j.egypro.2017.07.262

5. Thompson S, Si M (2014) Strategic analysis of energy efficiency projects: case study of a steel mill in Manitoba. Renew Sustain Energy Rev 40:814-819. https://doi.org/10.1016/j.rser.2014.07. 140

6. Tarrés J, Maas S, Scholzen F, Zürbes A (2014) Simulated and experimental results on heat recovery from hot steel beams in a cooling bed applying modified solar absorbers. J Cleaner Product 68:261-271. https://doi.org/10.1016/j.jclepro.2014.01.020

7. Chen L, Yang B, Shen X, Xie Z, Sun F (2015) Thermodynamic optimization opportunities for the recovery and utilization of residual energy and heat in China's iron and steel industry: a case study. Appl Therm Eng 86:151-160. https://doi.org/10.1016/j. applthermaleng.2015.04.026

8. Pili R, Romagnoli A, Spliethoff H, Wieland C (2017) Technoeconomic analysis of waste heat recovery with ORC from fluctuating industrial sources. Energy Procedia 129:503-510. https:// doi.org/10.1016/j.egypro.2017.09.170
9. Ramirez M, Epelde M, de Arteche MG, Panizza A, Hammerschmid A, Baresi M, Monti N (2017) Performance evaluation of an ORC unit integrated to a waste heat recovery system in a steel mill. Energy Procedia 129:535-542. https://doi.org/10.1016/j. egypro.2017.09.183

10. Nardin G, Meneghetti A, Dal Magro F, Benedetti N (2014) PCMbased energy recovery from electric arc furnaces. Appl Energy 136:947-955. https://doi.org/10.1016/j.apenergy.2014.07.052

11. Brandt C, Schuller N, Gaderer M, Kuckelkorn JM (2014) Development of a thermal oil operated waste heat exchanger within the off-gas an electric arc furnace at steel mills. Appl Therm Eng 66:335-345. https://doi.org/10.1016/j.appltherma leng.2014.02.003

12. Gaggioli W, Fabrizi F, Fontana F, Rinaldi L, Tarquini P (2014) An innovative concept of a thermal energy storage system based on a single tank configuration using stratifying molten salts as both heat storage medium and heat transfer fluid, and with an integrated steam generator. Energy Procedia 49:780-789. https:// doi.org/10.1016/j.egypro.2014.03.085

13. Lora EES, Nascimento MAR (2004) Thermoelectric generation: planning, design and operation (in Portuguese), vol 1. Interciência, Rio de Janeiro

14. Borgnakke C, Sonntag RE (2008) Fundamentals of thermodynamics. Wiley, New York

15. Santos CFP (2016) Thermoeconomic analysis and ecological efficiency of a thermoelectric power plant with chemical absorption of $\mathrm{CO}_{2}$ (in Portuguese). Dissertation (Master in Mechanical Engineering). São Paulo State University (UNESP), School of Engineering, Guaratinguetá

16. Vilela IAC (2007) Development of a thermoeconomic model which takes into account the environmental impacts (in Portuguese). Thesis (Doctor in Mechanical Engineering). São Paulo State University (UNESP), School of Engineering, Guaratinguetá

17. Jacobs JA, Schneider M (2009) Cogeneration application considerations. GE Energy, GER3430G (05/09). https://www. gepower.com/content/dam/gepower-pgdp/global/en_US/docu ments/technical/ger/ger-3430g-cogeneration-application-con siderations.pdf. Accessed 24 Aug 2017

18. OEDC Steel Committee (2015) Energy efficiency in the steel sector: why it works well, but not always. https://www.oecd.org/ sti/ind/Energy-efficiency-steel-sector-1.pdf. Accessed 28 Aug 2017

19. Economist Intelligence Unit (2012) Energy efficiency and energy savings: a view from the building sector. The economist. http:// www.bpie.eu/uploads/lib/document/attachment/16/EIU_Case Study_Report_2012.pdf. Accessed 28 Aug 2017 